\title{
ethic \\ O ELEMENTO PRESCRITIVO NO FENÔMENO MORAL: DESACORDOS ENTRE KANT E SCHOPENHAUER
} 型

\author{
THE PRESCRIPTIVE ELEMENT IN MORAL PHENOMENON: \\ DISAGREEMENT BETWEEN KANT AND SCHOPENHAUER
}

\author{
ROGÉRIO MOREIRA ORRUTEA FILHO ${ }^{1}$ \\ (UEL/Brasil)
}

AGUINALDO PAVÃO 2

(UEL/Brasil)

\begin{abstract}
RESUMO
Este artigo desenvolve-se em três seções. Na primeira seção, examina-se o desacordo manifestado por Schopenhauer em relação à Ética kantiana naquilo que tange à linguagem prescritiva da moral. Neste ponto, o desacordo surge por Schopenhauer julgar inadmissível atribuir qualquer função moralizante à filosofia, a qual, na visão do filósofo, deve permanecer puramente teórica e contemplativa. Entretanto, em nossa análise é mostrado que Kant não manifestou semelhante pretensão moralizadora. Na segunda seção, discute-se a tese schopenhaueriana de que a linguagem prescritiva teria origem na moral teológica, o que confirmaria, na visão de Schopenhauer, não só a contingência da relação entre os conceitos de moral e de dever, mas, em uma análise mais profunda, até mesmo a incompatibilidade entre ambos. Na terceira seção, argumentamos que, apesar de explicitamente negar o estatuto moral ao conceito de dever, a Ética de Schopenhauer implicitamente afirma-o. O motivo desta afirmação implícita se sustentaria sobre o fato inelutável de que os fenômenos morais são intrinsecamente prescritivos.
\end{abstract}

Palavras-chave: Ética; Dever; Prescrição.

\section{ABSTRACT}

This article is developed through three sections. In the first section, we examine the disagreement between Schopenhauer and Kant about the moral prescriptive language. At this point, the disagreement rises because Schopenhauer judges that the philosophy cannot have any moralizing function on human behavior: the philosophy must remain purely theoretical. However, our analysis shows that Kant never had such moralizing pretension. In second section, we discuss the schopenhauerian thesis about the theological origin of the prescriptive language, which Schopenhauer uses as a proof of the contingency between the concepts of morals and duty, and even of the contradiction between both. In the third section, we argue that even if Schopenhauer explicitly denies that the concept of duty is truly moral, 
however his own Ethics implicitly affirms it. The ground of such implicit affirmation sustains itself over this ineluctable fact: the moral phenomenon is intrinsically prescriptive.

Keywords: Ethics; Duty; Prescription.

\section{Introdução}

A fim de poder responder à pergunta "o que o filósofo vê quando pousa seus olhos sobre o fenômeno moral?" e, assim, estar em condições de apresentar e analisar os pontos de acordo e desacordo entre Kant e Schopenhauer, é necessário esclarecer em linhas gerais o que entendemos por fenômeno moral.

Por fenômeno moral nós entendemos um domínio da experiência humana em que a ação e a interação dos indivíduos são tomadas em consideração tendo em vista os juízos de louvor e censura. Nesse campo, regularmente estão presentes expectativas e exigências normativas. Daí ser um componente essencial do fenômeno moral a linguagem que empregamos para aplaudir e reprovar a ação e o caráter de outras pessoas. No fenômeno moral não apenas tornam-se salientes os juízos que fazemos, mas também as crenças e os sentimentos que acalentamos acerca do valor das ações alheias e das nossas próprias ações. Em suma, o fenômeno moral diz respeito às apreciações valorativas do agir humano, envolvendo assim nossos juízos, crenças e sentimentos morais. Esses, por sua vez, sempre reclamam certa mirada psicológica que lance alguma luz nas motivações que tornam inteligíveis a vida moral dos indivíduos.

É bem verdade que essa compreensão sumária do fenômeno moral não é suficiente para esclarecer o que está em jogo quando se pergunta sobre o que o "filósofo vê". Com efeito, o domínio do fenômeno moral pode ser contemplado sob diversas perspectivas, seja histórica, cultural, religiosa, antropológica ou psicológica, sem necessariamente envolver-se com tematizações filosóficas. Aliás, poder-se-ia dizer que não há uma tematização distintamente filosófica do fenômeno moral, isto é, que não há nada na experiência da moralidade que represente algo transepocal, invariável, universal. Talvez o que filósofo julgue ser universal não passe de um fenômeno histórico, culturalmente datado. Um pensador, como Kant por exemplo, pode pensar que a linguagem prescritiva reside no núcleo do fenômeno moral, cuja sondagem somente pode ser realizada com o olhar mui perspicaz do filósofo, ao passo que Schopenhauer, por sua 
vez, pode simplesmente alegar que a linguagem prescritiva é um fenômeno que reside na periferia da moralidade e expõe apenas o viés teológico que também compõe o cenário da vida moral quando vista como um campo de exploração não filosófica.

Tanto Kant como Schopenhauer concordam que o fenômeno moral somente se torna filosoficamente inteligível quando recorremos à metafísica, isto é, para ambos a inteligibilidade filosófica última do fenômeno moral não é uma inteligibilidade física, mas metafísica (em que pese os filósofos terem compreensões diferentes sobre o que significa metafísica). Todavia, eles veem coisas diferentes quando supostamente voltam seus olhos para o mesmo objeto, como também discordaram sobre os procedimentos de análise. Kant rejeita o exame empírico da moralidade. Já Schopenhauer acredita que não existem superpoderes oculares do filósofo que possam dispensá-lo do exame empírico.

Uma questão associada ao tema desse texto consiste em perguntar se existe um olhar autêntica e exclusivamente filosófico sobre a moral e em que consistiria esse olhar (se não seria um equívoco pensar que ele necessariamente implica teses com validade transepocal, invariável, universal). Mas enfrentar esse problema não é nosso propósito aqui. Registramos apenas que tentaremos, a partir de Kant e Schopenhauer, sugerir que é possível um olhar sobre o fenômeno moral que somente o filósofo estaria em condições de realizar e que esse olhar vê não o transitório, o mutável, o relativo, mas sim que esse olhar visa a penetrar no permanente, no imutável, no universal. Lamentamos que essa opinião tenha de ser, por ora, computada como um pressuposto assumido sem discussão.

\section{Fenômeno moral e linguagem prescritiva ${ }^{1}$}

De acordo com Kant, na filosofia prática "não temos de determinar os princípios do que acontece, mas sim leis do que deve acontecer, mesmo que nunca aconteça" (GMS, Ak 427) ${ }^{2}$. Schopenhauer se volta contra essa opinião e alega que a filosofia deve permanecer sempre teoria, pois "a sua essência é manter, perante todo objeto que a ela se oferece, o papel de simples espectador, do investigador; fazer prescrições não é o que lhe convém" (W I § 53, p. $285)^{3}$. Sendo assim, a finalidade de uma reflexão filosófica sobre a moral deve se limitar apenas à explicação das ações humanas (Cf. E 
II, § 4, p. 23 e ss. $)^{4}$. Consequentemente, o caráter prescritivo da filosofia moral de Kant não pode ser aceito.

Schopenhauer parece estar certo ao defender que o discurso filosófico não tem competência para dizer o que os homens devem ou não fazer. O que compete a ele é tão somente descrever o fenômeno moral, isto é, apreciar o que está implicado no agir. Para Schopenhauer, a ética deve ser descritiva e trilhar o caminho empírico. Ele se pronuncia claramente a favor da ideia de que a finalidade da ética consiste em "esclarecer, explicar e reconduzir à sua razão última os modos muito diferentes de agir dos homens no aspecto moral. Por isto, resta apenas para a descoberta do fundamento da ética o caminho empírico" (E II, § 13, p. 119).

No entanto, a alegada diferença de tratamento das questões morais entre a sua filosofia e a kantiana não é suficiente para a tomada de decisão sobre quem, por ventura, estaria certo, ou ao menos mais distante do erro. Com efeito, a pretensão que Schopenhauer atribui à filosofia moral também pode ser considerada a pretensão de Kant. Se Schopenhauer pretende com sua crítica voltar-se contra qualquer discurso moralizador, talvez ele tenha errado o alvo. Pode-se dizer que tampouco Kant pretende moralizar. A pretensão de Kant ao pousar seus olhos sobre o fenômeno moral é esclarecer o que significa agir moralmente. De acordo com Guido de Almeida, na Fundamentação da metafísica dos costumes Kant procura, atendendo ao que uma teoria filosófica sobre a moralidade tem de atender, responder a duas questões: "(1) O que devemos entender por 'dever moral'? (2) Por que acreditamos que temos 'deveres morais'?" (Almeida 1992: 95). Isso significa que, também para Kant, a filosofia deve evitar fazer prescrições, até porque o conceito de dever "reside já no bom senso natural (natürliche gesunde Verstand)" ${ }^{\prime}$, mais precisando "ser esclarecido do que ensinado" (GMS Ak 397$)^{6}$.

Isso que estamos argumentando converge perfeitamente com a definição kantiana de filosofia segundo a qual "a filosofia é o conhecimento racional a partir de meros conceitos" (Log A 22/Ak 23) ${ }^{7}$. A filosofia apenas visa à exposição de conceitos e não à sua construção. Essa segunda tarefa pertence à matemática, também uma espécie de conhecimento racional. Kant quer, com essa definição, chamar a atenção para o fato de que, na filosofia, os conceitos não são construídos pelos filósofos. São conceitos dados e, como ele alerta na Crítica da razão pura, as definições filosóficas devem ser entendidas apenas como "exposições de conceitos dados" (KrV B 758) e, por isso, 
não podem ser confundidas com as definições matemáticas, que são "construções de conceitos originariamente formados" (KrV B 758). Por conseguinte, boa vontade, dever, mandamento, lei moral e imperativo são conceitos que a filosofia tematiza a fim de esclarecer noções constitutivas do fenômeno moral, ou se quisermos, para repetir o linguajar de Kant, já presentes no entendimento moral comum. Sendo assim, o apelo inicial da acusação de Schopenhauer parece perder bastante o seu peso.

Com efeito, a tarefa do filósofo, para Kant, estaria muito longe de qualquer proselitismo, pois sequer caberia ao filósofo a construção dos conceitos por ele tematizados. De acordo com Schopenhauer, "seria tão tolo esperar que nossos sistemas morais e éticos criassem caracteres virtuosos, nobres e santos, quanto que nossas estéticas produzissem poetas, artistas plásticos e músicos" (W I $\S 53$, p. 354). Mas se Schopenhauer pretende atingir Kant com a observação de que livros de filosofia moral não fomentam virtudes em seus leitores, assim como livros de estética não produzem artistas, ele erra o objeto mirado. Com efeito, Kant não pretende com a Fundamentação ou a Crítica da razão prática tornar os homens melhores moralmente. Embora Kant declare que a filosofia moral pura ajude a evitar a corrupção (Verderbnis) dos costumes (Cf. GMS, Ak 390), podemos considerar essa declaração como inessencial para o propósito filosófico de sua reflexão moral, a saber, buscar e estabelecer o princípio supremo da moralidade (Cf. GMS, Ak 392). Não pensamos que Kant pudesse crer que o conhecimento profundo - ou talvez apenas superficial - dos argumentos e sutilezas conceituais de uma Fundamentação produzissem efeitos morais no estudioso dessa obra. Cremos não comportar polêmica a afirmação de que também Kant diria que livros de ética não tornam os homens moralmente melhores. Nesse sentido, os dois autores concordariam sobre as ambições meramente teóricas da reflexão filosófica sobre o fenômeno moral.

Mas presumivelmente Schopenhauer insistiria sobre o equívoco da afirmação de Kant na Fundamentação de que na filosofia prática, como citado, "não temos de determinar os princípios do que acontece, mas sim leis do que deve acontecer, mesmo que nunca aconteça" (GMS, Ak 427). Cabe, pois, indagar: é coerente sustentar que a filosofia prática, embora não deixe de visar à elucidação do fenômeno moral (à explicação do dado), cujo coração seria a crença que acalentamos na ideia de dever moral, ainda tenha concomitantemente a pretensão de determinar leis do que deve acontecer, mesmo que 
nunca aconteça? O que significa "determinar leis do que deve acontecer, mesmo que nunca aconteça"? Acreditamos que Kant possa ser defendido se entendermos que "determinar", nesse contexto, não significa impor leis, a exemplo da imposição de leis que um soberano político pode fazer em relação a seus súditos. Determinar leis significa estabelecer, por análise, quais são as leis do dever moral. Significa, portanto, analisar, explicar, sem fazer exortações e desviar o olhar do fenômeno moral, fugindo dos fatos ou, como diria um kantiano, dos dados da razão que reclamam esclarecimento.

Intimamente ligada à crítica à suposta índole prescritiva da filosofia moral kantiana está o argumento de Schopenhauer contra a natureza categórica do imperativo da moralidade em Kant. Schopenhauer pretende mostrar que nenhum imperativo pode ser categórico, pois para ele só existem imperativos hipotéticos. 0 imperativo da moralidade em Kant quer ser uma coisa que nenhum imperativo poderia ser (Cf. E II, § 7, p. 67 e ss.). No nosso entendimento, a crítica de Schopenhauer à natureza prescritiva da ética em Kant parece não entender que o caráter prescritivo do fenômeno moral significa tão-somente que o sujeito, ao reconhecer o valor moral de uma determinada ação (ou princípio da ação), reconhecerá, ao mesmo tempo, que tal ação ou princípio traz consigo uma exigência para seu acatamento, quer dizer, ele reconhecerá que há uma razão para agir com base nesse princípio ${ }^{8}$. Isso, como se pode ver, não implica qualquer proselitismo filosófico, mas simplesmente o reconhecimento de como funcionaria moralmente o entendimento comum.

\section{Moralidade e teologia}

Mas Schopenhauer poderia dizer que não é esse exatamente o ponto, isto é, que não se trata simplesmente de reconhecer o modo de funcionamento do fenômeno moral, ou, se quisermos, não se trataria do mero reconhecimento do "modo de ser" do entendimento moral comum. Ele poderia insistir na ideia de que, se o olhar do filósofo fizer um acurado exame do fenômeno moral, não perceberá nele nenhuma forma imperativa. Apenas um olhar filosoficamente limitado e destituído de sutilezas históricas ou genealógicas deixaria de notar que a forma imperativa da moralidade repousa em fundamentos teológicos (E II, § 4). Acreditamos que aqui estamos diante de um desacordo decisivo entre Kant e Schopenhauer ${ }^{9}$. 
Com efeito, para o autor da Fundamentação a forma imperativa da moral, tal como ele pensa ter esclarecido e justificado, não tem qualquer fundamento teológico, do contrário a autonomia da vontade jamais poderia ser o "princípio supremo da moralidade" (GMS, Ak 440). A fim de dar conta de seu declarado objetivo, como já dito, o da "busca e fixação do princípio supremo da moralidade" (GMS, Ak 392), Kant entende que não basta esclarecer como os homens agem, mas como devem agir. Segundo sua perspectiva, se o olhar filosófico sobre o fenômeno moral tivesse de se restringir ao exame empírico das ações humanas, tal estudo não pertenceria mais à filosofia moral, não diria respeito mais à "moral propriamente dita" (GMS, Ak 388). Um exame das ações humanas baseado na experiência deve receber o nome de "antropologia prática", constituindo-se, assim, no que Kant entende ser justamente a parte empírica da ética. Deve-se, contudo, reconhecer que Schopenhauer está atento a isso. Sua discordância parece ser uma discordância radical. No $\S 13$ de Sobre o fundamento da moral, ele retoma esse ponto. Ele alega que os olhos do filósofo devem mirar o fato de como os homens efetivamente agem, e não supostos princípios, visíveis apenas aos olhos da razão, sobre como os homens devem agir.

Talvez se queira objetar-me que a ética nada tem a ver com o fato de como os homens efetivamente agem, mas que ela é a ciência de como devem agir. Mas é justo esse princípio que eu nego [...], o conceito de dever e a forma imperativa da ética só são válidos na moral teológica e perdem todo o sentido e significação fora dela (E II, § 13, p. 119).

Como se percebe, a discussão sobre as diferentes visões de Kant e Schopenhauer sobre o fenômeno moral, e por consequência, sobre suas divergentes concepções de filosofia moral nos conduzem à discussão sobre a suposta presença, disfarçada, da teologia no centro da ética de Kant. Ora, sobre esse ponto, o que parece ter sido alcançado por Schopenhauer revela o singelo fato de que os conceitos de dever e a forma imperativa da ética também são conceitos empregados pela moral teológica ${ }^{10}$. Contudo, não nos parece que Schopenhauer tenha conseguido estabelecer que eles somente adquirem sentido dentro da moral teológica. Schopenhauer argumenta com uma alegação implícita não justificada segundo a qual os conceitos de dever, lei e mandamento são necessariamente teológicos. Ora, não 
é lícito inferir do fato de eles serem encontrados na moral teológica que eles são necessariamente teológicos.

Admitamos que os conceitos de dever, lei e mandamento sejam constituintes da moral teológica e da moral kantiana. Disso não podemos, sem mais, pensar que eles sejam qualificadores exaustivos de nenhuma delas. De fato, não são, pois na moral teológica é preciso recorrer ao conceito de Deus e na moral kantiana ao conceito de autonomia da vontade (sem Deus evidentemente, visto que, por definição, autonomia da vontade implica autossuficiência moral do indivíduo). Poder-se-ia conceder a Schopenhauer procedência em sua crítica se ele restringisse o seu alcance apenas à Crítica da razão pura ${ }^{11}$. Realmente, no Cânon da KrV, há elementos abonadores à leitura de Schopenhauer. Na KrV, Kant sustenta a necessidade de a razão admitir a existência de Deus e a imortalidade da alma a fim de não se considerar as leis morais como "vãs quimeras, pois a consequência necessária que a razão vincula a essas leis, sem estes pressupostos, está condenada a desaparecer" (KrV B 839). Quer dizer, Kant na Crítica da razão pura, entenderia que os olhos do filósofo contemplam um objeto ineludivelmente teológico no interior do fenômeno moral.

Porém, a visão mais refletida de Kant, aquela da Fundamentação e da Crítica da razão prática, permite a alegação de que, sobre esse ponto, isto é, sobre moralidade e Deus, os autores estão numa posição de concordância. Quando o filósofo (isso vale para Kant e Schopenhauer afortunadamente) pousa seus olhos sobre o fenômeno moral, ele não vê Deus. Ele não apenas não vê um ser divino moralmente legislador, como tampouco vê um ser humano acolhido pelos braços de um Deus assistencial. Penso que tanto para Kant como para Schopenhauer o que conta em termos morais para esse ser humano é sua plena soberania como ser moralmente responsável ${ }^{12}$. Claro que eles, embora olhem supostamente para o mesmo fenômeno moral, não identificam exatamente os mesmos objetos, e nisso residem seus mais profundos desacordos sobre a experiência moral, destacadamente sobre a natureza prescritiva ou não do fenômeno moral.

Julgamos que nossa opinião sobre os desacordos entre Kant e Schopenhauer tenha ficado saliente até aqui. Todavia, não será talvez totalmente ocioso sublinhar que, a nosso ver, o entendimento comum revela aos olhos do filósofo um material moral pré-filosófico já constituído de elementos prescritivos. Assim, cabe ao filósofo moral, 
como sua primeira tarefa (talvez, para alguns, primeira e única) explicá-los e analisá-los de tal modo que eles possam ser elevados a níveis mais rigorosos de generalização ou de homogeneidade, quiçá extraindo da aparente diversidade deles um princípio unificador. Não acreditamos que se possa abordar o fenômeno moral sem reconhecer que ele carrega consigo exigências recíprocas entre os indivíduos, tornando significativas críticas e elogios morais? ${ }^{13}$

\section{A ética de Schopenhauer é implicitamente prescritiva?}

Foi mostrado até aqui que o desacordo de Schopenhauer em relação a Kant deu-se por sua rejeição ao componente prescritivo atribuído por Kant ao fenômeno moral. Mais especificamente, a crítica schopenhaueriana ao componente prescritivo da moral poderia ser dividido em dois pontos: 1) a Ética não pode ser prescritiva porque, enquanto parte da Filosofia, trata-se de um saber meramente descritivo, cuja finalidade é o esclarecimento ou compreensão de um dado fenômeno, e não a formação de pessoas moralmente melhores; 2) a forma prescritiva da própria linguagem moral é apenas um aspecto acidental desta, porque possui raiz histórica/cultural na moral "teológica".

Quanto ao primeiro ponto, nossa posição já fora suficientemente esclarecida: concluímos que Schopenhauer errou o alvo de suas críticas ao acusar em Kant uma finalidade teórica totalmente estranha ao seu projeto. Tal como Schopenhauer, também Kant almejava apenas a descrição do fenômeno moral. Portanto, sua teoria era destituída de ambições pedagógicas, no sentido de pretender melhorar o caráter moral das pessoas. Agora coloca-se a seguinte questão: é possível sustentar uma moral normativa (ou prescritiva) ao mesmo tempo destituída de pretensões pedagógicas quanto ao caráter e ações da espécie humana? Aqui convém repetir as palavras de Edmund Husserl, para quem a filosofia moral de Schopenhauer conservava-se normativa, apesar de destituída de pretensões quanto à moralização do comportamento humano: "Schopenhauer [...], que rejeitou em princípio toda moralização prática conduzido por sua doutrina do caráter inato, tem uma ética no sentido de uma ciência normativa [...]. Pois ele não abandonou, de modo algum, as distinções em valor moral" (HUSSERL, 2001, p. 37).

$E$ isto nos conduz ao nosso segundo ponto desta seção. É plenamente concebível uma ética normativa (ou prescritiva... usamos 
as duas expressões como sinônimas no atual contexto) sem que a mesma seja moralizante, ou, conforme expressão de Husserl (2001, p. $37)$, tecnológica, no sentido de sustentar objetivos práticos. Pelo trecho supracitado de Husserl, é possível perceber que este estabeleceu uma relação intrínseca entre forma normativa e valor moral. Logo, nos termos de Husserl, se a filosofia de Schopenhauer comporta valores morais, então esta filosofia também precisa constituir uma ciência normativa. E para provar isso, pretendemos agora mostrar que o próprio Schopenhauer não conseguiu evitar de implicitamente expressar-se através da linguagem do "dever" e da consequente forma imperativa, apesar de explicitamente rejeitá-las como supostamente impostas pela moral teológica. Passemos agora a expor os argumentos que sustentam esta hipótese.

Como Schopenhauer nos alerta em Sobre a quádrupla raiz do princípio de razão suficiente, não se deve confundir conceitos com palavras (G, §20, p. 54). Isso significa que a expressão verbal pela qual é exposta uma ideia não é ainda esta ideia mesma, mas apenas um artifício da linguagem pelo qual se espera descrever um possível aspecto dela. Diferentes palavras podem ser usadas para nos referirmos a uma mesma coisa e, portanto, uma mesma coisa pode ser descrita por diferentes expressões verbais. Dito de modo mais simples: é plenamente possível sustentar diferentes sentidos sobre um mesmo objeto de referência.

Pois bem: quando Schopenhauer aponta na mera articulação verbal dos judeus a origem da moral do dever, e isso simplesmente porque no decálogo judeu utilizou-se a forma imperativa, parece-nos que neste ponto Schopenhauer confunde uma mera expressão verbal com a totalidade do conceito ao qual aquela expressão se refere. É perfeitamente possível formular uma norma moral, cuja estrutura verbal subjacente é a de um dever-ser, sem, no entanto, precisarmos articular verbalmente o verbo "dever". Se alguém diz, por exemplo, "ame o próximo como a ti mesmo", nota-se que o verbo "dever" não está expresso na frase, mas nem por isso sua estrutura verbal subjacente deixa de enunciar um dever, e é por isso que podemos reformular a mesma frase com o acréscimo do verbo "dever", sem que a mesma perca em nada de seu sentido original: "deves amar o próximo como a ti mesmo". Podemos também deixar de empregar a forma imperativa na mesma frase, por exemplo ao dizer "seria ótimo se todos amassem seu próximo como amam a si mesmos". E, apesar de agora ela se parecer mais com uma simples expressão de um 
desejo, nem por isso a sua estrutura subjacente deixou de ser imperativa. Pois no fundo, o que se quer expressar com aquele desejo é a regra de que todos deveriam amar uns aos outros como amam a si mesmos.

O mesmo raciocínio pode ser empregado sobre, por exemplo, os cinco preceitos budistas, que igualmente recusam o emprego explícito do verbo "dever" e a forma imperativa. O primeiro deles afirma: "eu tomo o preceito de abster-me de matar outros seres vivos". Mais uma vez, é possível reformular a mesma regra com o acréscimo do verbo "dever", sem que a mesma perca em nada de seu sentido: "deves abster-se de matar outros seres vivos". E esta reformulação só é possível porque aquela regra, apesar de sua expressão verbal não conter a palavra "dever", no entanto sustenta-se sobre uma estrutura verbal subjacente e mais profunda, e cujo sentido é o de um deverser.

E por que o sentido subjacente em todos estes exemplos é o de um dever-ser? Resposta: pelo fato de que as condutas preceituadas (por cristãos ou pelos budistas) não se encontram em um contexto de indiferença moral, ou, em outras palavras, há um valor em jogo. Para Husserl (2001, p. 36), "é 'normativa' toda proposição que impõe uma condição necessária, ou suficiente, ou necessária e suficiente para se ter um tal predicado". E o predicado ao qual ele se refere é um de tipo valorativo, como "bom". Se, por exemplo, eu digo que "o soldado deve ser corajoso", isso significa que "o soldado, para ser bom, deve ser corajoso" (o exemplo é do próprio Husserl). Logo, onde há valor, há norma ou dever, e vice-versa. Nestes termos, se a filosofia de Schopenhauer oferece as condições teóricas pelas quais é possível qualificar algo como "bom" em termos morais (e sem dúvida oferece), então sua filosofia deve conter "a condição necessária ou suficiente" pela qual é possível tal qualificação ou atribuição de predicados, isto é, deve conter normas.

Mas por que esta condição - seja necessária ou suficiente para a obtenção do predicado valorativo - há de ser expressa em termos deônticos? Por que o sentido subjacente das proposições morais é de "dever-ser"? Por que não bastaria dizer "o soldado, que é bom, é corajoso"?

Dever e liberdade 
Parece-nos que há pelo menos três respostas para isso. A primeira e mais tradicional, é a de que apenas a cópula do "deve" correlaciona-se à liberdade do agente, e o discurso moral supõe essa liberdade, isto é, a possibilidade de desajuste entre as escolhas do agente e o valor moral prevalecente, tal como o juízo de valor "o soldado que é bom, é corajoso". É por isso que o discurso moral não pode se limitar a juízos de valores, mas, a partir destes, este discurso precisa estender-se a prescrições ${ }^{14}$. Eu só digo "tu deves" porque a pessoa a quem o comando é endereçado pode agir diferente. Conforme nota Marcel Conche (2006, p. 4), se a "liberdade do agente moral é uma ilusão, disso decorreria decerto que jamais teríamos o direito de ir além da simples constatação do que acontece, além de simples juízos constatativos". Em Kant, há uma relação recíproca entre as duas noções. Por um lado, julga-se que se pode a partir da consciência do que se deve (cf. KpV, B 54), e assim o "deve" imposto pela lei moral seria a ratio congnoscendi da liberdade. Porém, também não haveria sentido em admitir uma imposição normativa àquele que não é livre, de sorte que a liberdade é ratio essendi da lei moral (cf. KpV, B 5). Também Kelsen (2006, p. 87 e ss.) associa a forma fundamental das proposições jurídico-normativas ("se $A$, então $B$ deve ser") àquilo que ele chamou de "princípio da imputação", e que guarda analogia com o princípio da causalidade sem com ele identificar-se, na medida em que, sob o princípio da imputação, expressam-se normas destituídas de necessidade natural, justamente porque conduzidas a partir de "atos de vontade", e que, além disso, encontram no ato ou pessoa do agente (Kelsen julga supérflua a separação entre a pessoa e seus atos particulares) um "ponto terminal", para além do qual não se questiona por uma causa antecendente ${ }^{15}$.

Justamente neste ponto alguém poderia contrapor-se, a partir de Schopenhauer, alegando que o conceito de livre-arbítrio (vale dizer, a possibilidade de executar ações alternativas) é destituído de significado, uma vez que todas as ações estão igualmente submetidas ao princípio de razão suficiente, pelo simples fato de que é inconcebível ao nosso entendimento o conceito de qualquer efeito destituído de uma causa ou, em sentido mais lato, de um fundamento, a partir do qual o evento segue-se necessariamente. Deste modo, argumenta Schopenhauer que mesmo as ações humanas são impensáveis se desacompanhadas de um motivo, pois as ações são apenas a exteriorização do querer individual, e o querer, por sua vez, é "impensável" sem um motivo (cf. E I, II, p. 51). Portanto, a relação 
entre ações/querer e motivos é tão necessária quanto a relação entre um efeito e sua causa; logo, não haveria um poder de agir de outro modo.

Porém, não devemos nos esquecer que Schopenhauer adota igualmente o dualismo kantiano fenômeno/coisa-em-si. A necessidade do querer a partir de motivos vige apenas no contexto do mundo considerado como representação. Conforme o próprio Schopenhauer, o nosso sentimento interno de responsabilidade revela-nos que nosso querer não possui apenas uma extensão fenomênica, mas também metafísica e que transcende os domínios da razão suficiente; do contrário, não nos sentiríamos moralmente responsáveis (cf. E I, V, p. 134 e ss.). E segundo Schopenhauer, sentimo-nos responsáveis por aquilo que somos; logo, se me sinto responsável por aquilo que sou, isso só pode significar que eu poderia ser outro, isto é, ter um outro caráter (cf. E I, V, p. 134 e ss.).

Portanto, em Schopenhauer, não se revoga o poder ou liberdade moral. Esta liberdade moral é apenas deslocada da ação para o caráter e, o que é o mesmo, desloca-se do fenomênico para o metafísico. Talvez o máximo que um schopenhaueriano poderia nos contrapor aqui é que não haveria sentido em falar de imperativos sobre ações específicas (por exemplo, "não deves matar", "não deves mentir"), pois todos estes imperativos seriam apenas expressões superficiais de um único imperativo mais fundamental: "deves ser bom", ou, o que é o mesmo no contexto da filosofia de Schopenhauer, "deves ser compassivo", "deves ser abnegado", etc. De qualquer forma, subsistiria um dever implícito na Ética de Schopenhauer, e provar isso é aqui nosso único propósito.

E agora podemos retomar aquele questionamento inicial: por que não dizer "o soldado, que é bom, é corajoso", em lugar de "o soldado, para ser bom, deve ser corajoso"? Uma resposta possível é a de que a primeira afirmação já pressupõe a posse do soldado sobre o predicado "bom". Trata-se, portanto, de uma proposição meramente constatativa de um fato que já ocorre. Mas se o soldado ainda não possui o atributo "bom", então ele precisa alcançar o meio necessário para isso, que é a virtude da coragem, e assim o discurso transita para a forma deôntica. Em outras palavras, somente o discurso de estrutura subjacente deôntica é compatível com um estado de privação (no caso, do predicado "bom") e com a possibilidade de obtenção do atributo faltante. Isso significa que o sentido subjacente do "dever" e a possibilidade de realização ética (isto é, a liberdade) são noções 
correlacionadas. No contexto da filosofia de Schopenhauer isso ainda se aplica, apenas com o acréscimo de que aquela "possibilidade de realização ética" (ou simplesmente liberdade) adquire, em Schopenhauer, um sentido mais metafórico, uma vez que se refere a um ato de vontade livre que não está nem no espaço e nem no tempo ${ }^{16}$, e portanto não pode ser literalmente descrito pela linguagem usual, que é representacional. Tratar-se-ia, por assim dizer, de um evento metafísico, cujo sentido é apenas negativo, enquanto evento que não é fenomênico ou empírico, enquanto evento que não se conduz pelas formas de espaço, tempo e causalidade.

Dever e necessitação

Agora, enfrentaremos uma possível segunda objeção à tese de que há deveres implícitos em Schopenhauer. Ao comentar as teses de Schopenhauer que buscam desqualificar a noção de dever, Harald Köhl (1997, p. 150) resume-as nos seguintes pontos:

1. Para Schopenhauer, todo dever só tem significado (isto é, só pode ser pensado) na sua relação com um castigo ou recompensa. Logo, para Schopenhauer todo dever é hipotético, e por isso todo imperativo é hipotético (aliás, este ponto já fora assinalado na primeira seção deste texto);

2. O que reforça o ponto anterior é a suposta origem histórica da moral imperativa: o dever moral origina-se da moral teológica e, portanto, está numa relação com a retribuição divina.

3. Uma ação subordinada a uma prescrição, que por sua vez impõe uma sanção, não tem valor moral. Afinal, nestes termos só se realiza a ação por um motivo egoísta, isto é, pelo medo do castigo ou desejo pela recompensa.

A partir disso, conclui Köhl: ou o dever moral não tem qualquer relação com sanções, e assim ele também não tem significado (pois o dever só pode ser pensado na sua relação com sanções); ou ele tem relação com sanções, mas aí é destituído de valor moral. Portanto, Schopenhauer nunca pretendeu revogar o sentido de dever e de imperativos pura e simplesmente, mas apenas intencionou provar que os mesmos não possuem significado no contexto dos comportamentos dotados de genuíno valor moral. 
E quais ações seriam dotadas de genuíno valor moral? Somente aquelas inteiramente destituídas de móbiles egoístas, a "justiça espontânea" e a "caridade desinteressada", motivadas unicamente pelo sentimento de compaixão (cf. E II, §16, p. 132 e ss). Já a noção de "dever" só faria sentido num contexto de resistência interior à justiça e à caridade. Apenas neste contexto de resistência interior é que a justiça e a caridade enunciam-se como "deveres". E esta equação entre moral e resistência interior, cujo resultado é o conceito de dever, pode ser encontrada já em Kant, quando este define "dever" como "necessitação prática", o que pressupõe a possibilidade de discordância entre as máximas do indivíduo e o "princípio objetivo dos seres racionais" (GMS, Ak 434). Em contraposição, supõe Schopenhauer que para o homem compassivo é natural ser justo ou caritativo, e por isso seu comportamento é verdadeiramente "espontâneo" e "desinteressado". Mas em caso de resistência interior, isto é, quando a moral espontânea cede lugar à moral prescritiva, qual seria a motivação do agente? Eis a resposta de Schopenhauer: o medo do castigo ou desejo de recompensa (cf. E II, §6, p. 40 e ss.; §7, p. 68 e ss.). Em outras palavras, se a justiça e a caridade revestem-se de forma imperativa, então só podem valer como imperativos hipotéticos, cuja condição é o desejo pessoal de satisfação de motivações egoístas.

Mas a nosso ver, tais argumentos parecem depender em demasia de uma antropologia um tanto ingênua, porque pressupõem uma dicotomia radical entre ações totalmente espontâneas ou compassivas e ações inteiramente forçadas ou egoístas. Entretanto, o caráter humano pode ser representado, sem qualquer contradição, dentro de um quadro muito mais complexo que isso. Um homem pode ser compassivo, ou melhor, predominantemente compassivo, e mesmo buscando a justiça com a maior boa vontade, ele sempre terá, em seu interior, inclinações contrárias ao sacrifício exigido pela justiça. $O$ próprio Schopenhauer nos oferece trechos que abonam este ponto de vista, uma vez que:

a) Em Sobre o fundamento da moral, Schopenhauer admite que "as três motivações morais dos homens, o egoísmo, a maldade e compaixão, estão presentes em cada um numa relação incrivelmente diferente" (E II, §20, p. 195), e por isso "cada qual só será estimulado predominantemente pelos motivos para os quais tem uma sensibilidade preponderante" (E II, §20, p. 197). Lamentavelmente, Schopenhauer não extraiu as consequências destas premissas. Ora, se 
cada caráter individual carrega consigo uma síntese das três diferentes motivações em proporções sempre diferentes, de modo que só se pode falar da "preponderância" de uma ou outra motivação, disso se segue que, mesmo no caráter predominantemente compassivo, poderá haver eventuais conflitos internos, e justamente porque ainda haveria algo de egoísta nele (ou até mesmo cruel). Portanto, agir do modo justo ou caritativo não pode ser inteiramente fácil ou totalmente espontâneo mesmo para o homem de caráter compassivo. Pensar de outro modo seria pressupor a existência de alguém não predominantemente, mas totalmente compassivo, o que o próprio Schopenhauer não admite.

b) No capítulo 48 dos Suplementos ao Mundo como vontade e representação, Schopenhauer escreve que "verdadeira retidão, inviolável justiça, aquela primeira e mais importante virtude cardeal, é um fardo tão difícil, que aquele que se dedica a ela incondicionalmente e do fundo de seu coração, há de fazer sacrifícios que tiram da vida a doçura que a tornam agradável" (W II, cap. 48, p. 709). Assim, temse um trecho no qual Schopenhauer admite que "dificuldade" e "sacrifício" são vivenciados mesmo por aquele que se dedica à justiça "do fundo de seu coração". Portanto, Schopenhauer não tem em vista aqui os homens motivados pelo egoísmo e, no entanto, as sensações de dificuldades e sacrifícios fazem-se igualmente presentes. No contexto da vida de homens puramente compassivos - isto é, homens destituídos de resistência interior para com as demandas da justiça, uma vez que toda justiça é desinteressada e espontânea - não faria sentido em falar-se de dificuldades e sacrifícios: para tais homens, o sacrifício consistiria apenas em não ser justo para com o próximo.

c) Em vários momentos Schopenhauer demonstra apreço pelo dogma cristão do pecado original, cuja mensagem ele considerava uma verdade fundamental sobre o homem, e que expressa a "condição ímpia de nosso estado natural e a corrupção do homem natural" (P II, $\S 181$, p. 427). É realmente difícil de imaginar como no contexto de semelhante antropologia filosófica, profundamente pessimista sobre a condição humana, possam surgir caracteres inteiramente destituídos de tensões morais internas. Para homens de constituição pecadora é impossível que a justiça e a caridade sempre se realizem de modo totalmente espontâneo, sem um senso, ainda que mínimo, de autossacrifício. Fazer o bem nunca é fácil, pois mesmo no melhor dos 
homens, há impedimentos subjetivos que provocam nele uma terrível e angustiante batalha interna ${ }^{17}$.

Portanto, ao supor ações morais decorrentes de um puro sentimento de compaixão totalmente livre de resistências e tensões interiores, Schopenhauer parece introduzir arbitrariamente um forte elemento otimista em sua própria antropologia pessimista. Além disso, ele pressupõe a existência de um tipo de caráter do qual é razoável supor não existir exemplo empírico algum, contrariando, assim, sua própria regra metodológica, segundo a qual "toda a filosofia é sempre teórica, já que lhe é sempre essencial manter uma atitude puramente contemplativa [...] e sempre inquirir, em vez de prescrever regras" (W I, §53, p. 353).

\section{Dever e necessidade moral}

A terceira hipótese, e que nos parece não possuir precedentes, é a de que apenas a cópula do "deve" garante coerência interna às proposições morais. E isso por uma razão muito simples: na esfera do Ser (e aqui não nos referimos a domínios ontológicos, mas à estrutura da proposição cujo sentido subjacente é melhor expresso pela cópula "é"), não há violação ao princípio da não-contradição em dizer, por exemplo, "X matou um homem inocente", tanto quanto não há em dizer "X salvou a vida de um homem inocente". Trata-se apenas de "juízos constatativos" ou "descritivos", e neste sentido, qualquer um daqueles fatos é igualmente possível.

Apenas quando reformulamos o mesmo conteúdo das mesmas proposições, mas agora pela cópula do "deve", é que uma das proposições preenche nossa consciência como louvável, e, portanto, necessária em algum sentido ("X deve salvar a vida de um inocente"), e a proposição oposta, como condenável, e por isso, impossível em algum sentido ("X deve tirar a vida de um inocente"). Mas esta necessidade e esta impossibilidade (cujos correlatos são os juízos de louvor ou de censura) não podem ser puramente lógicas ${ }^{18}$ (isto é, apenas por não violarem o princípio da não-contradição), simplesmente porque no âmbito do puramente lógico (que se expressa pela cópula do "é") aquelas proposições são igualmente possíveis, e por isso nenhuma delas é logicamente necessária e nem impossível. Mas sabemos que uma delas é necessária, e que por isso, a proposição oposta é inadmissível. E sabemos disso num sentido moral, e não meramente lógico. Portanto, o moralmente necessário (isto é, aquilo 
que não pode sê-lo de outro modo num contexto moral) e o moralmente devido significam a mesma coisa, pois somente pela cópula do dever faz sentido falar-se numa necessidade moral. Isso significa que apenas sob o pressuposto de um valor (por exemplo, o de que preservar a vida inocente é um bem) e da cópula do dever (a partir do qual estabelece-se a condição necessária ou suficiente para a predicação valorativa, conforme já explicado), é que o discurso moral adquire um sentido objetivamente comunicável.

Estes argumentos não se referem à possibilidade de o agente agir diferente, e também independem de considerações antropológicas sobre o homem (por exemplo, sobre sua constituição pecadora ou sua resistência interior às "leis objetivas da razão pura"), essenciais ao conceito de "dever" enquanto "necessitação". Estes argumentos aduzem ao simples fato de que o conteúdo de uma determinada proposição moral não pode ser outro, sem ser objeto de um juízo de censura, e esta impossibilidade de ser outro pressupõe um "deve" subjacente. Trata-se daquilo que julgamos ser uma análise puramente semântica das proposições morais, e o resultado ao qual chegamos é o de que estas proposições só fazem sentido (só podem ser objetivamente comunicadas) por meio da cópula "deve", esteja ela implícita ou explícita na proposição.

Em suma: só há necessidade moral no contexto de proposições cujo sentido subjacente é expresso pelo verbo "dever". Excluído o "dever", sobram apenas juízos descritivos cujo sentido subjacente é de um "é", e no âmbito do Ser não há necessidade e nem contradição moral, mas apenas possibilidade moral, exigindo-se aqui apenas a condição de que não se viole, na mesma proposição, o princípio da não-contradição. Torna-se então paradigmática para nós a parte inicial da primeira definição que Kant formula do "dever", na Fundamentação da metafísica dos costumes: "dever é a necessidade de uma ação" (GMS, Ak 400). Apenas complementaríamos esta definição pela qualificação do tipo de necessidade da ação à qual apenas o dever se refere: dever é a necessidade moral de uma ação. Para adequarmos nossa fórmula às exigências teóricas de Schopenhauer, bastaria substituir "ação" por "modo de ser", ou "caráter".

Para retornarmos ao problema inicial: se a filosofia de Schopenhauer não é moralmente indiferente, então isso significa que no contexto de sua filosofia há necessidade moral. E se há necessidade moral, então há dever, pois apenas pela cópula do dever é pensável uma necessidade moral. 
Poderíamos então resumir nossos últimos argumentos - pelos quais buscou-se provar que a filosofia de Schopenhauer encerra uma Ética prescritiva implícita - nos seguintes pontos:

- A filosofia de Schopenhauer é moralmente indiferente? Resposta: não, pois nela sustenta-se valores.

- Se sustenta valores, então realiza juízos de louvor e de censura. Isto é bastante óbvio, pois Schopenhauer condena atos cruéis e egoístas, e louva a compaixão e abnegação.

- Se louva a compaixão, isto significa que a compaixão é, em algum sentido, necessária, isto é, não há possibilidade de ser de outro modo, sem ser ao mesmo tempo objeto de um juízo de censura, afinal, as alternativas à compaixão são o egoísmo e a maldade.

- Porém, a compaixão não pode ser onticamente necessária, isto é, não se pode falar da necessidade moral da compaixão em proposições cuja estrutura subjacente é um "é", pois, conforme já explicado, em proposições deste tipo só há possibilidades morais, e nenhuma necessidade moral.

- Apenas proposições cuja estrutura subjacente é um "deve" fornecem as condições para que se expresse necessidade moral com um sentido objetivamente comunicável. Logo, se para Schopenhauer a compaixão é moralmente necessária, então mesmo Schopenhauer só pode expressar esta necessidade em termos deônticos, ainda que implicitamente.

\section{Conclusão}

Parte significativa do desacordo de Schopenhauer em relação à Ética de Kant gira em torno da questão sobre se o elemento prescritivo é ou não essencial aos fenômenos morais. Buscou-se mostrar neste artigo que, em que pese os argumentos contrários de Schopenhauer, o referido elemento prescritivo parece ser essencial à moral. Afinal, conforme fora exposto, os argumentos de Schopenhauer são insuficientes para provar o contrário, pois, conforme mostrado nas seções 1 e 3 deste artigo, uma Ética normativa não precisa ser necessariamente acompanhada de pretensões pedagógicas; sustentar uma Ética normativa não equivale a "ensinar a virtude", como acusa Schopenhauer no início do $\$ 53$ de 0 mundo como vontade e representação. De acordo com a interpretação por nós assumida, o ensino da virtude jamais fora o objetivo da ética kantiana. 
Além disso, o argumento de Schopenhauer segundo o qual a linguagem moral-imperativa é um fato historicamente condicionado, não prova a arbitrariedade do elemento prescritivo, mas, conforme argumentamos na seção 2, Schopenhauer apenas demonstra com isso que a moral teológica também se utiliza desta mesma linguagem prescritiva, o que não significa que esta última seja exclusividade dela. É perfeitamente possível pensar que a moral teológica, ao impor prescrições, está com isso apenas expressando um dado intrínseco à consciência moral comum. Claro, neste ponto alguém poderia objetarnos sob a alegação de que Schopenhauer demonstrou que a noção de dever só tem sentido no contexto de uma crença religiosa que afirme haver uma relação necessária entre nossas escolhas e os castigos e recompensas impostas por Deus.

Para enfrentar este ponto e reforçar nossa constatação de que o elemento prescritivo é essencial à moral, buscamos expor na seção 3 nossa tese de que a Ética do próprio Schopenhauer é implicitamente prescritiva, apesar de explicitamente recusar todo valor moral ao conceito de dever. Neste ponto, argumentamos que Schopenhauer não pôde fugir à linguagem do dever, uma vez que este último sempre aparece como estrutura verbal subjacente de proposições moraisvalorativas (proposições estas que estão inequivocamente presentes na filosofia de Schopenhauer), e isso ocorre porque (1) há uma correlação necessária entre dever e liberdade moral, (2) entre dever e necessitação, (3) e apenas proposições morais cuja estrutura subjacente seja a de um dever-ser podem ser objetivamente comunicáveis. Logo, Schopenhauer só deixaria de ser um filósofo prescritivista sob a hipótese de ele assumir um posicionamento puramente determinista (o que ele não faz), ou de negar o fato empírico da resistência interior humana aos reclames da justiça e caridade (o que igualmente não pode ocorrer no contexto de sua antropologia pessimista), ou de pretender expor uma filosofia moral incomunicável (o que seria absurdo).

Por estas razões, parece-nos acertado por ora concluir que o conceito moral do dever não é algum artifício teórico originado pelo capricho de filósofos afastados da realidade, ou que tal conceito apenas reflita escolhas culturais contingentes. Ao contrário: enquanto noção imanente à consciência moral comum, o conceito de dever insere-se neste fenômeno enquanto parte constituinte e indissociável do mesmo, e exatamente por isso, o ato de negá-lo explicitamente sempre virá acompanhado de sua afirmação implícita ${ }^{19}$. Logo, se tal como o próprio 
Schopenhauer supõe, o objeto da Ética é a compreensão comum da moral, então pode-se aqui levantar uma dúvida sobre se Schopenhauer, ao não conceder cidadania moral e filosófica ao conceito de dever, não foi acometido de uma miopia filosófica quando dirigiu sua atenção para o fenômeno moral. 


\section{Notas:}

${ }^{1}$ Possui graduação em Direito pela Faculdade de Ensino Superior Dom Bosco (2010) e mestrado em Filosofia pela Universidade Estadual de Londrina - UEL (2014). Atualmente é doutorando em Filosofia pela Universidade Estadual de Londrina - UEL. Leciona as disciplinas de Filosofia do Direito na Faculdade de Ensino Superior Dom Bosco, além de atuar no ensino técnico como professor de Legislação em Segurança do Trabalho. É integrante do Núcleo de Pesquisa Schopenhauer-Nietzsche (UEL).

2 Doutor em Filosofia pela Unicamp (2005), com tese sobre "O mal moral em Kant". Em 1998 defendeu dissertação de mestrado na UFRGS intitulada "Liberdade e moralidade em Kant". Atualmente é Professor Associado da Universidade Estadual de Londrina.

1 Esse texto recupera, nas partes 1 e 2, a argumentação desenvolvida nas seções 2 e 3 de Pavão, 2009, p. 135-148.

2 Citaremos as obras de Schopenhauer através das seguintes siglas: E I, para Über die Freiheit des menschlichen Willens (Sobre a liberdade da vontade humana); E II para Sobre o Fundamento da Moral; G para Über die vierfache Würzel des Satzes vom zureichenden Grunde (Sobre a quádrupla raiz do princípio de razão suficiente); P II para Parerga und Paralipomena, tomo II; W I para $O$ mundo como vontade e representação; W II para o segundo tomo de Die Welt als Wille und Vorstellung (o mundo como vontade e representação).

Para as obras de Kant, as siglas utilizadas serão: GMS para Fundamentação da metafísica dos costumes; KrV para Crítica da razão pura; KpV para Crítica da razão prática; Log para Lógica. As siglas serão seguidas de indicações sobre edição utilizada (edições $A, B$ ou da academia [Ak]).

${ }^{3}$ Itálicos nossos.

${ }^{4}$ E II, § 4, p. 23: "Digo, contrapondo-me a Kant, que em geral tanto o ético quanto 0 filósofo tem de contentar-se com a explicação e com o esclarecimento do dado, portanto com o que é". Veja também sobre esse ponto em Cacciola (1994, p. 154 e ss).

5 A tradução dessa expressão não nos parece uma tarefa fácil. Traduzir natürliche gesunde Verstand por são entendimento natural talvez pudesse ser aceito pela sua literalidade, mas afigura-se uma opção pouco adequada. Apesar de termos dúvidas acerca da alternativa de Quintela, não conseguimos vislumbrar uma melhor. As coisas seriam mais simples se Kant tivesse usado a expressão do título da primeira seção, gemeinen sittlichen Vernunft.

${ }^{6}$ A bem da verdade, poderíamos dizer que não se trata de mais ou menos, ou seja, de precisar de menos ensinamento e mais esclarecimento. Numa perspectiva meramente filosófica, a razão moral comum precisa apenas de esclarecimento. 
${ }^{7}$ Cf. também KrV B 741, B 865 e 868.

${ }^{8}$ Esse ponto é muito bem assinalado por Walker (1999, p. 18).

${ }^{9}$ Para Kant, uma desconstrução genealógica ou histórica do conceito de dever seria a própria desconstrução do fenômeno moral.

${ }^{10}$ A partir da seção 3, esperamos poder tornar claro que a forma prescritiva não é exclusividade da moral teológica.

${ }^{11}$ Esse ponto é corretamente assinalado por Young (Cf. 1984, p. 209).

12 Não está em questão aqui discutir se Schopenhauer logrou êxito em sua tentativa de justificar os juízos de responsabilidade moral. Sobre esse tópico específico, que nos seja concedida a permissão para citarmos os trabalhos de Orrutea Filho (2019) e Pavão (2019).

${ }^{13}$ Esse é um dos pontos que Tugendhat considera ausente na reflexão moral de Schopenhauer e que denunciaria seu fracasso em entender a moralidade (Cf. 1997, p. 197).

14 Na teoria exposta no $\S 14$ dos Prolegômenos à lógica pura, Husserl parece derivar proposições normativas a partir de juízos valorativos que não são normativos (dizer que um soldado deve ser corajoso pressupõe um juízo de valor segundo o qual o bom soldado é corajoso). Embora ele não seja explícito neste ponto, é possível que sua passagem do juízo de valor para a proposição normativa (que parece operar uma paradoxal transição do É para o Deve) ocorre por pressupor a liberdade do agente, isto é, sua potência para ajustarse ou ao não aos padrões estabelecidos pelo juízo valorativo fundamental. Esta também é a interpretação apresentada por Pedro Alves (2015, p. 183) no seguinte trecho: "assim, a esfera normativa seria um campo de comandos ou imperativos assente num plano axiológico e num plano teorético mais fundamentais, campo para o qual poderia ser dada a seguinte fórmula de derivação: do juízo tético 'Só um $A$ que é $B$ tem a qualidade $C^{\prime}$, segue-se o juízo de valor 'só um $A$ que tem $C$ é um bom $A$ ', e, finalmente, o comando ' $A$ deve ser $B^{\prime}$, que prescreveria para a esfera dos factos - aqui, dos agentes e das acções -, como uma exigência objectiva a que esses factos estariam necessariamente submetidos. Esta não é, porém, uma necessidade ôntica [...]; ela exprimiria, antes, uma necessidade deôntica, assente numa prescrição, a qual deixa margem para uma liberdade de decisão que pode querer ou não querer estar em conformidade com a norma, necessidade que poderia enunciar-se assim: 'se $x$ é um guerreiro, e se $x$ quer ser um bom guerreiro, então x tem necessariamente de ser um guerreiro corajoso'" (grifo nosso).

15 "Na descrição da ordem normativa da conduta dos homens entre si é aplicado aquele outro princípio ordenador, diferente da causalidade, que podemos designar como imputação. [...] a ligação que exprime na proposição jurídica tem um significado completamente diferente daquela que a lei natural 
descreve, ou seja, a da causalidade. Sem dúvida alguma que o crime não é ligado à pena [...] como uma causa é ligada ao seu efeito. Na proposição jurídica não se diz, como na lei natural, que, quando $A$ é, $B$ é, mas que, quando $A$ é, $B$ deve ser, mesmo quando $B$, porventura, efetivamente não seja. O [...] significado da cópula [...] na proposição jurídica [...] resulta da circunstância de a ligação na proposição jurídica ser produzida através de uma norma estabelecida pela autoridade jurídica - através de um ato de vontade, portanto - enquanto que a ligação de causa e efeito [...] é independente de qualquer intervenção dessa espécie" (KELSEN, 2006, p. 87). "O número de elos de uma série imputativa não é, como o número de elos de uma série causal, ilimitado, mas limitado. Existe um ponto terminal da imputação" (KELSEN, 2006, p. 101). "Precisamente sobre esta distinção fundamental entre imputação e causalidade, sobre o fato de que há um ponto terminal da imputação mas não um ponto terminal da causalidade, se baseia a oposição entre a necessidade, que domina na natureza, e a liberdade que dentro da sociedade existe e é essencial para as relações normativas dos homens" (KELSEN, 2006, p. 102).

16 "Como é fácil perceber, este caminho nos conduz para o fato de que nós não devemos procurar mais a obra de nossa liberdade - como faz a opinião usual - em nossas ações singulares, mas no Ser e Essência total do homem, que deve ser pensado como um ato livre, que se expõe em uma pluralidade e diversidade de ações apenas à faculdade de conhecimento ligada ao tempo, espaço e causalidade" (E I, V, p. 137-138).

17 Se levarmos em consideração a descrição do Evangelho de Mateus, parecenos que até mesmo Cristo teria experimentado no Getsêmani a angústia que decorre da tensão interior entre aquilo que se quer, e aquilo que se deve: "Pai, se for possível, afasta de mim esse cálice, contudo não se faça como eu quero, mas como Tu queres".

18 Utilizamos aqui os termos "lógica pura", ou "puramente lógico", no mesmo sentido que Luiz Fernando Coelho (1981, p. 103 e ss.), quando este contrapõe a "lógica geral" ou "lógica pura" (que se projetam na "ordem do ser") à "lógica jurídica" (dever-ser). Com base nisso, poderíamos ainda falar de uma "lógica moral" (que é mais ampla que a jurídica, mas que também se projeta no âmbito do dever-ser), e é a este tipo de "lógica moral" que se refere esta subseção.

${ }^{19}$ Aqui convém citar Husserl novamente: "dados evidentes são pacientes, deixam as teorias falar o que quiserem para eliminá-los, mas continuam sendo o que são" (HUSSERL, 2006, p. 66). 


\section{Referências Bibliográficas}

ALMEIDA, G. A. de. "Moralidade e Racionalidade na Teoria Moral Kantiana". In ROHDEN, V. (org). Racionalidade e Ação. Porto Alegre: UFRGS e Instituto Goethe, 1992, p. 94-103.

ALVES, Pedro M. S. Juízos e normas para uma fenomenologia dos actos téticos e dos actos nomotéticos. In: Manuscrito - Rev. Int. Fil., Campinas, v. 38, n.1, pp. 167-205, jan.-jun. 2015.

CACCIOLA, M. L. M. Schopenhauer e a questão do dogmatismo. São Paulo: Edusp, 1994.

COELHO, L. Fernando. Lógica jurídica e interpretação das leis. 2. ed. Rio de Janeiro: Forense, 1981.

CONCHE, Marcel. O fundamento da moral. Tradução de Marina Appenzeller. São Paulo: Martins Fontes, 2006.

HUSSERL, Edmund. Ideias para uma fenomenologia pura e para uma filosofia fenomenológica. Tradução de Márcio Suzuki. São Paulo: Ideias e Letras, 2006.

. Logical investigations. Volume I (Prolegomena to pure logic). Tradução de J. L. Findlay. New York: Routledge, 2001.

KANT, I. Werke in Zwölf Bande. Ed. W. Weischedel. Frankfurt: Surkamp, 1991.

- Crítica da razão prática. Tradução com introdução e notas de Valério Rohden. São Paulo: Martins Fontes, 2002.

- Crítica da razão pura. Tradução de Manuela Pinto dos Santos e Alexandre Fradique Morujão. Lisboa: Calouste Gulbenkian, 1994.

. Fundamentação da metafísica dos costumes. Tradução de Paulo Quintela. Porto: Porto Editora, 1995.

- Lógica. Tradução de Guido de Almeida. Rio de Janeiro: Tempo Brasileiro, 1992.

KELSEN, Hans. Teoria pura do direito. Tradução de João Baptista Machado. São Paulo: Martins Fontes, 2006.

KÖHL, Harald. Schopenhauers Kritik am moralischen Sollen. In: INGEKAMP, Heinz Gerd; BIRNBACHER, Dieter; BAUMANN, Lutz. 
Schopenhauer-Jahrbuch 78 (1997). Würzburg: Königshausen \& Neumann, 1997, pp. 147-159.

ORRUTEA FILHO, Rogério Moreira. Individualidade em sentido moral e justiça eterna. Voluntas: Revista Internacional de Filosofia, Santa Maria, v. 10, n. 1, p. 186-198, jan./abr. 2019.

PAVÃO, A. Kant e Schopenhauer sobre a natureza da filosofia moral. Dissertatio (UFPel), v. 30, p. 135-148, 2009.

- Responsabilidade moral e justiça eterna em Schopenhauer. Voluntas: Revista Internacional de Filosofia, Santa Maria, v. 10, n. 3, p. 212-229, set./dez. 2019.

SCHOPENHAUER, Arthur. Die Welt als Wille und Vorstellung, zweiter Band. Ed. de Arthur Hübscher. Zürich: Diogenes, 1977.

O mundo como vontade e como representação. Primeiro tomo. Tradução, apresentação, notas e índices por Jair Barboza. São Paulo: Unesp, 2005.

- Sobre o fundamento da moral. Tradução de Maria Lúcia Cacciola. São Paulo: Martins Fontes, 2001.

- Parerga und Paralipomena. zweiter Band. Ed. de Arthur Hübscher. Zürich: Diogenes, 1977.

- Über die Freiheit des menschlichen Willens. Ed. de Arthur Hübscher. Zürich: Diogenes, 1977.

TUGENDHAT, E. Lições sobre Ética. Tradução do grupo de doutorandos do Curso de Pós-Graduação em Filosofia da UFRGS, revisão e organização da tradução de Ernildo Stein e Ronai Rocha. Petrópolis: Vozes, 1997.

WALKER., R. Kant: Kant e a lei moral. Tradução de Oswaldo Giacóia Junior. São Paulo: Ed. Unesp, 1999.

YOUNG, J. "Schopenhauer's Critique of Kantian Ethics". Kant-Studien 75 (2), 1984, p. 191-212. 